\title{
Hazard Baseline Downgrade Effluent Treatment Facility
}

by

A. Blanchard

Westinghouse Savannah River Company

Savannah River Site

Aiken, South Carolina 29808

M. A. Nadeau

WSMS

S. Patel

WSMS

DOE Contract No. DE-AC09-96SR18500

This paper was prepared in connection with work done under the above contract number with the U.S. Department of Energy. By acceptance of this paper, the publisher and/or recipient acknowledges the U. S. Government's right to retain a nonexclusive, royalty-free license in and to any copyright covering this paper, along with the right to reproduce and to authorize others to reproduce all or part of the copyrighted paper. 


\section{DISCLAIMER}

This report was prepared as an account of work sponsored by an agency of the United States Government. Neither the United States Government nor any agency thereof, nor any of their employees, makes any warranty, express or implied, or assumes any legal liability or responsibility for the accuracy, completeness, or usefulness of any information, apparatus, product, or process disclosed, or represents that its use would not infringe privately owned rights. Reference herein to any specific commercial product, process, or service by trade name, trademark, manufacturer, or otherwise does not necessarily constitute or imply its endorsement, recommendation, or favoring by the United States Government or any agency thereof. The views and opinions of authors expressed herein do.not necessarily state or reflect those of the United States Government or.any agency thereof.

This report has been reproduced directly from the best available copy.

Available to DOE and DOE contractors from the Office of Scientific and Technical Information, P. O. Box 62, Oak Ridge, TN 37831; prices available from (423) 576-8401.

Available to the public from the National Technical Information Service, U. S. Department of Commerce, 5285.Port Royal Road, Springfield, VA 22161. 


\section{DISCLAIMER}

Portions of this document may be illegible in electronic image products. Images are produced from the best available original document. 


\title{
HAZARD BASELINE DOWNGRADE
}

\section{EFFLUENT TREATMENT FACILITY (U)}

\author{
M. A. Nadeau \\ S. M. Patel, Task Leader
}

September 1998

\begin{tabular}{|c|}
\hline DOES NOT CONTAIN \\
UNCLASSIFIED CONTROLLED \\
NUCLEAR INFORMATION \\
Reviewing fufatel \\
Official: $\frac{\text { S.M. Patel }}{9-15-98}$ \\
Date:
\end{tabular}

Westinghouse Savannah River Company Aiken, SC 29808

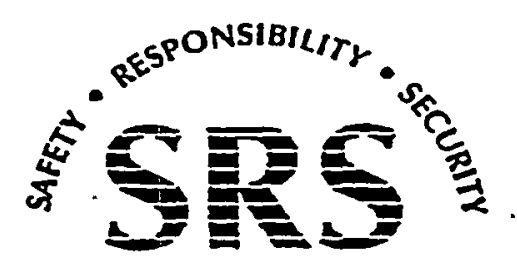

PREPARED FOR THE U.S. DEPARTMENT OF ENERGY UNDER CONTRACT NO. DE-ACO9-96SR18500 
KEYWORDS: Baseline Grouping Assessment

ETF

Solid Waste

\title{
HAZARD BASELINE DOWNGRADE
}

\section{EFFLUENT TREATMENT FACILITY (U)}

\author{
M. A. Nadeau \\ S. M. Patel, Task Leader
}

September 1998

Westinghouse Savannah River Company Aiken, SC 29808

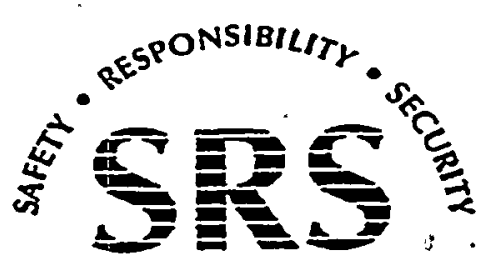

SAVANNAH RIVER SITE

PREPARED FOR THE U.S. DEPARTMENT OF ENERGY UNDER CONTRACT NO. DE-ACO9-96SR18500 
Westinghouse Savannah River Company

Hazard Baseline Downgrade Effluent Treatment Facility

Rev. 1
WSRC-TR-98-00092

WSMSC-98-0077
Project:

Document:

Title:

Approvals:

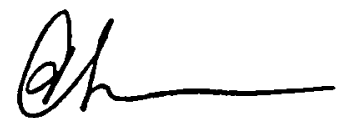

C. C. Kuhn, Technical Reviewer, WSMS

Restated

S. M. Patel, Task Lead, WSMS

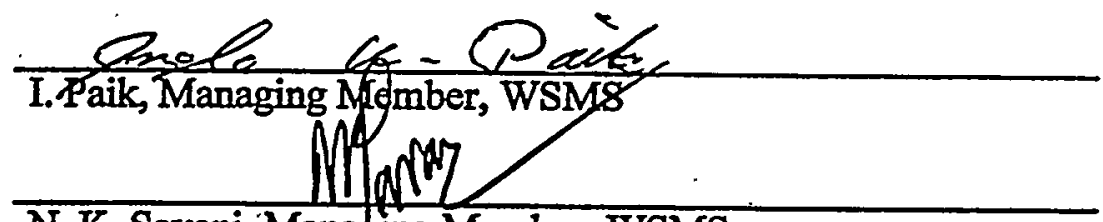

N.K. Savaii, Managing Member, WSMS

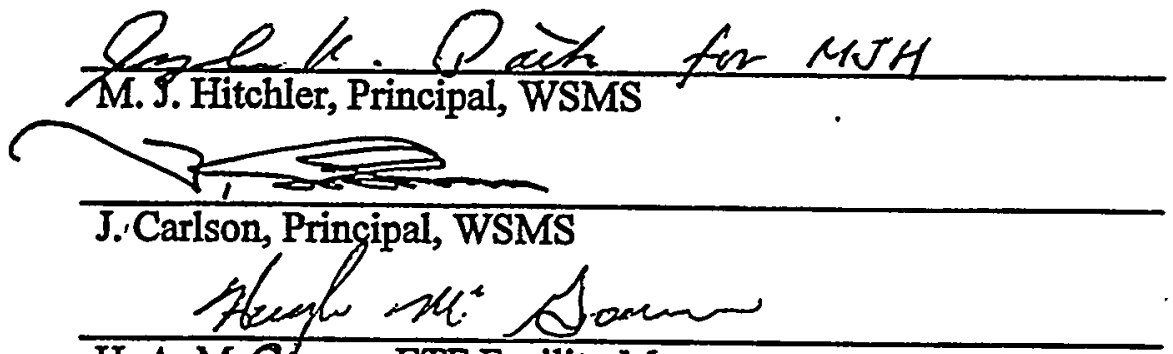

H. A. Megoverp, ET F Facility Manager

Cinteabetu

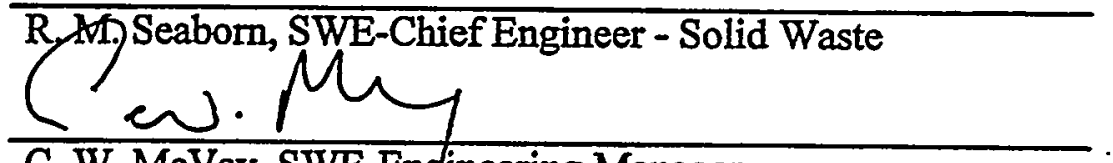

C. W. McVay, SWE-Engineering Manager

$\frac{A, \omega, \omega}{\text { A. W. Wiggins, SWE- }}$

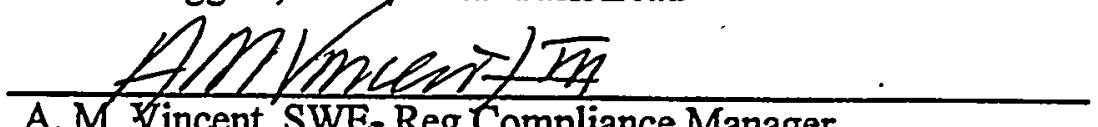

A.M. Vincent, SWE-Reg Compliance Manager

$$
\frac{9-2-98}{\text { Date }} \frac{9-2-98}{}
$$

Date

$\frac{9-2-98}{\text { Date }}$

$9 / 3 / 28$

Date

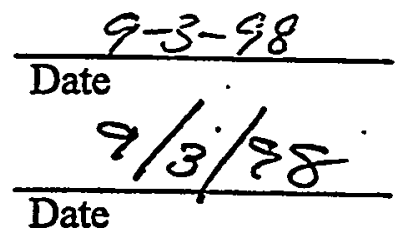

$9-10-98$

Date

$9 \cdot 16 \cdot 98$

Date

$9 / 10 / 98$

Date

$9 / 9 / 98$

Date

$\frac{9 / 8 / 98}{\text { Date }}$

ii 


\section{EXECUTIVE SUMMARY}

This Hazard Baseline Downgrade reviews the Effluent Treatment Facility (ETF), in accordance with Department of Energy (DOE) Order 5480.23 (Ref. 1), WSRC 11Q Facility Safety Document Manual (Ref. 2), DOE-STD-1027-92 (Ref. 3), and DOE-EM-STD-5502-94 (Ref. 4). It provides a baseline grouping based on the chemical and radiological hazards associated with the facility. The determination of the baseline grouping for ETF will aid in establishing the appropriate set of standards for the facility.

This assessment has strictly applied the evaluation criteria of DOE-STD-1027-92 and DOE-EM-STD-5502-94. This assessment applies the guidance of DOE-EM-STD-5502-94 for defining the facility's baseline grouping. DOE-EM-STD-5502-94 was prepared for DOE Environmental Management facilities as a road map to the safety and health hazard identification requirements contained in DOE Orders.

Given that the assumptions identified herein are maintained, the ETF is considered a Radiological Facility. Furthermore, the results of the Baseline Grouping Assessment indicate that an Auditable Safety Analysis and a Health and Safety Plan are required for the facility. The results and conclusions of this assessment are not valid for radiological inventories greater than those used in the analysis, but are valid if controlled within Hazard Category 3 threshold limits. It should be noted that additional inventory due to holdup in the process area and other temporary sources were not included in the calculations for this evaluation. Therefore inventories in each of the facility segments must be controlled as described in WSRC-TR-00257 (Ref. 5) to ensure that Hazard Category 3 threshold limits for a Radiological Facility (Ref. 3) are not exceeded.

The chemical hazards for the ETF were not evaluated as part of Revision 0 of this Hazard Baseline Downgrade; however, a Baseline Grouping Assessment for hazardous chemicals is performed as a part of Revision 1. The ETF has been evaluated to be a Low Hazard chemical facility based on the chemical inventory. The evaluation of chemical hazards does not affect the downgrade of the ETF to a Radiological Facility. 
TABLE OF REVISIONS

$\underline{\text { Revision }}$ 1
Affected Pages

All
Description of Revision

Changes in segmentation, addition of chemical hazards' assessment, inclusion of radionuclide inventory control 
1.0 BACKGROUND

2.0 HAZARD BASELINE ASSESSMENT 1

$2.1 \quad$ Facility Description.................................................................................................1

2.2 Baseline Grouping ......................................................................................................2

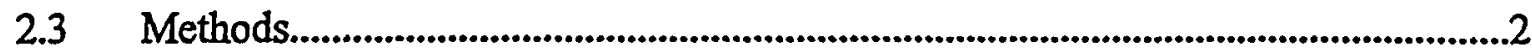

2.3.1 Radiological inventory Assessment Methodology ...................................2

2.3.2 Chemical inventory Assessment Methodology .........................................4

2.4 Waste Stream Review ........................................................................................5

2.5 Hazardous Material Inventory .................................................................................6

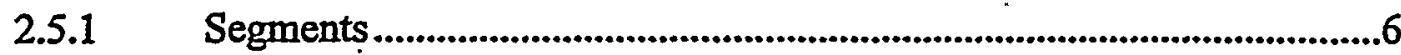

2.5.1.1 Segment 1- F-Area Cooling Water Basin ............................6

2.5.1.2 Segment 2 - F-Area Retention Basin..................................6

2.5.1.3 Segment 3 - H-Area Cooling Water Basin..........................6

2.5.1.4 Segment 4 - H-Area Retention Basin..................................6

2.5.1.5 Segment 5-Lift Stations, Force Main, Wastewater Collection Tanks and Organic Removal ........................................................................7

2.5.1.6 Segment 6 - Treatment Building, Control Building, Outside Tanks, and HEPAs.................................

2.5.2 Radiological Inventory............................................................................7

2.5.3 Chemical Inventory................................................................................

2.6 Implementation of Radionuclide Inventory Control ....................................................8 


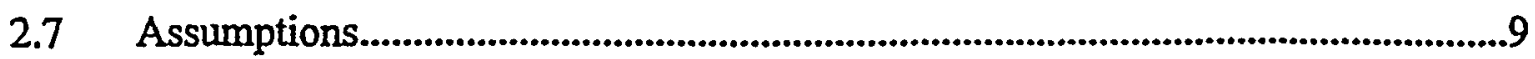

2.8 Hazardous Material Inventory Assessment....................................................................9

2.8.1 Radiological Inventory Assessment...........................................................9

2.8.2 Chemical Inventory Assessment...........................................................9

$2.9 \quad$ Hazard Baseline Results and Conclusions .................................................................10

2.9.1 Radiological Results .............................................................................10

2.9.2 Chemical Results .......................................................................................10

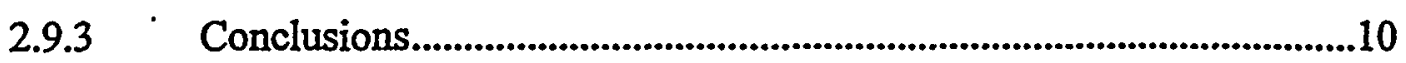

3.0 Downgrade Results and Conclusions.........................................................................12

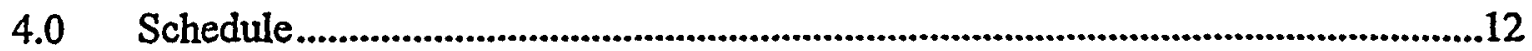

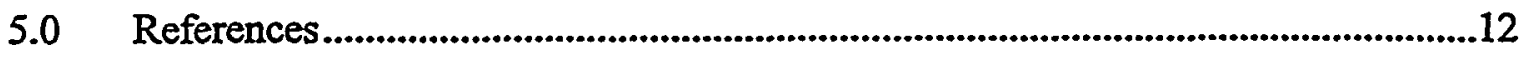




\section{LIST OF FIGURES}

\section{Page}

1 Determination of Baseline Grouping ..........................................................................15 


\section{LIST OF TABLES}

\section{Page}

1 Radiological Inventory Evaluation of the ETF Facility Segments 16

2 Chemical Inventory Evaluation of The ETF Facility Segments... ... 17 


\section{ACRONYMS}

$\begin{array}{ll}\text { AB } & \text { Authorization Basis } \\ \text { ANS } & \text { American Nuclear Society } \\ \text { ANSI } & \text { American Nuclear Standards Institute } \\ \text { ASA } & \text { Auditable Safety Analysis } \\ \text { BRA } & \text { Baseline Risk Assessment } \\ \text { CFR } & \text { Code of Federal Regulations } \\ \text { Ci } & \text { Curies } \\ \text { DOE } & \text { Department of Energy } \\ \text { EPA } & \text { Environmental Protection Agency } \\ \text { ETF } & \text { Effluent Treatment Facility } \\ \text { HAD } & \text { Hazards Assessment Document } \\ \text { HASP } & \text { Health and Safety Plan } \\ \text { HEPA } & \text { High Efficiency Particulate Air } \\ \text { PHR } & \text { Process Hazard Review } \\ \text { PSO } & \text { Program Secretarial Officer } \\ \text { RCA } & \text { Radiologically Controlled Area } \\ \text { rem } & \text { Roentgen Equivalent Man } \\ \text { RQ } & \text { Reportable Quantity } \\ \text { SAR } & \text { Safety Analysis Report } \\ \text { SRS } & \text { Savannah River Site } \\ \text { TPQ } & \text { Threshold Planning Quantity } \\ \text { TQ } & \text { Threshold Quantity } \\ \text { WAC } & \text { Waste Acceptance Criteria } \\ \text { WSMS } & \text { Westinghouse Safety Management Solutions } \\ \text { WSRC } & \text { Westinghouse Savannah River Company } \\ & \end{array}$


This page intentionally blank 


\subsection{BACKGROUND}

This Hazard Baseline Downgrade lowers the Hazard Baseline for the Effluent Treatment Facility (ETF) to Radiological Facility. The Baseline Grouping Assessment supercedes the Hazards Assessment Document (HAD) for the Effluent Treatment Facility (Ref. 6) for the chemical and radiological hazards associated with the ETF.

At the time Reference 6 was prepared, DOE-STD-1027-92 (Ref. 3) had not yet been issued. This Hazard Baseline Downgrade has been prepared using thresholds from DOE 5480.23 (Ref. 1) and DOE-STD-1027-92. The current Waste Acceptance Criteria (WAC) (Ref. 7) are the primary basis for determining facility inventory. The guidance provided in DOE-EM-STD-5502-94 (Ref. 4) was applied in determining the Hazard Baseline using current facility information.

The Authorization Basis $(A B)$ is as currently described in the SWMD Authorization Basis Lists Manual (Ref. 8). The AB List will ultimately be revised to reflect the safety basis documents required as a result of this downgrade.

\subsection{HAZARD BASELINE ASSESSMENT}

\subsection{FACILITY DESCRIPTION}

The ETF, located in $\mathrm{H}$ Area, collects and treats process wastewater, which may be contaminated with small quantities of radionuclides and process chemicals. Based on the effectiveness of the treatment, $99 \%$ of this wastewater may be discharged to the environment. The primary sources of wastewater include F-Area and H-Area Canyon Outside Facilities, F-Area laboratories, F/H Tank Farm evaporator overheads and F/H Tank Farm stormwater drainage. Other miscellaneous sources include ER Purge Water.

Wastewater collection tanks receive wastewater from two lift stations, one in F-Area and one in H-Area. The wastewater is stored and chemically pretreated.

The wastewater is then transferred to the Filtration System, which removes suspended solids and transfers the filtered water to an Organic Removal System. The Organic Removal System then removes any heavy metals and organics from the water. The wastewater continues on to the Reverse Osmosis (RO) System. Here dissolved solids are removed and the cleaned water is discharged to the Ion Exchange System, which removes cesium, strontium and heavy metals that may still be present in the water. Filter and RO concentrate streams and cleaning solutions are sent to the Evaporator System, which further concentrates the waste prior to its transfer to Tank .50 in the H Tank Farm ITP.

Water leaving the Ion Exchange System is collected in the Treated Water Tanks until samples are analyzed to verify that discharge requirements are met. Once it is verified that specifications are 
met, the treated wastewater is released to Upper Three Runs Creek via a regulated outfall (Ref. 10).

\subsection{BASELINE GROUPING}

A "Nonreactor Nuclear Facility" is defined in DOE Order 5480.23 (Ref. 1), Section 5.k, as ... "...those activities or operations that involve radioactive and/or fissionable materials in such form and quantity that a nuclear hazard potentially exists to the employees or the general public. Included are activities or operations that: (1) produce, process, or store radioactive liquid or solid waste, fissionable materials, or tritium; (2) conduct separations operations; (3) conduct irradiated materials inspection, fuel fabrication, decontamination, or recovery operations; (4) conduct fuel enrichment operations; or (5) perform environmental remediation or waste management activities involving radioactive materials. Incidental use and generating of radioactive materials in a facility operation (e.g., check and calibration sources, use of radioactive sources in research and experimental and analytical laboratory activities, electron microscopes, and $\mathrm{x}$-ray machines) would not ordinarily require the facility to be included in this definition."

A facility is defined in DOE-EM-STD-5502-94 (Ref. 4), as a "Non-Nuclear Facility" "...if the amount of radioactive material potentially releasable from a facility is less than the Reportable Quantity (RQ) value listed in Appendix B to Table 302.4 of 40 CFR 302 and the amount of potentially releasable hazardous material exceeds the RQ values listed in Table 302.4 to $40 \mathrm{CFR}$ 302."

A "Radiological Facility" is defined in DOE-EM-STD-5502-94, as "...those with an inventory of radiological materials below the levels as defined in DOE-STD-1027-92, but above the RQ value listed in Appendix B to Table 302.4 (per 40 CFR 302). "A facility is defined in DOE-EM-STD5502-94 (Ref. 4), as an "Industrial Facility" if the amount of radioactive material potentially releasable from a facility is less than the RQ value listed in Appendix B to Table 302.4 of 40 CFR 302 and the amount of potentially releasable hazardous chemicals is less than the $R Q$ values listed in Table 302.4 to 40 CFR 302.

The ETF meets the definition of a Radiological Facility, as discussed in this document.

\subsection{METHODS}

DOE-EM-STD-5502-94 (Ref. 4) is used to provide overall guidance for this graded approach. Figure 1 illustrates DOE-EM-STD-5502-94 guidance for identification of a facility's baseline grouping.

\subsubsection{RADIOLOGICAL INVENTORY ASSESSMENT METHODOLOGY}

The criteria for determining the radiological hazard categorization of facilities are provided in DOE-STD-1027-92 (Ref. 3). In DOE Order 5480.23 (Ref. 1), three hazard categories are 
defined. A facility is designated as Hazard Category 1 if the analysis shows the potential for significant offsite consequences, Hazard Category 2 if the hazards analysis shows the potential for significant onsite consequences, and Hazard Category 3 if the analysis shows the potential for significant localized consequences only. A facility that does not exceed the Hazard Category 3 threshold criteria but still possesses some amount of radioactive material is considered a Radiological Facility.

The inventory assessment conducted to determine the hazard categorization is performed without credit taken for engineered features or administrative controls. Examples of engineered features and administrative controls are those specific facility features (not including site location) such as building containment, stacks, equipment, systems, actions, or operating conditions, that are established to control risk.

In general, the radiological evaluation is accomplished by comparing the inventory of each radionuclide to the threshold quantities provided in Table A.1 of DOE-STD-1027-92. In addition, the quantity of mixed fission products is also considered (Ref. 3). If a facility's radionuclide inventory meets or exceeds the Hazard Category 3 threshold quantity, the facility is classified as a nuclear facility. Facilities that do not meet or exceed the Hazard Category 3 threshold quantity are evaluated to determine if they are a Radiological Facility, a Non-nuclear Facility or an Industrial Facility. The criteria for differentiating between a Non-nuclear Facility and an Industrial Facility are provided in Section 2.3.2.

Once a facility is determined to be a nuclear facility, a specific hazard categorization is determined. The criteria for determining the hazard categorization of nuclear facilities based on the radiological evaluations are established as follows:

- Hazard Category 1

- The facility has the potential for significant offsite consequences based on total curie content, potential material forms, and maximum energy for dispersion available. Only Category A Reactors or facilities designated by the Program Secretarial Officer (PSO) are designated as Hazard Category 1 in accordance with the directions of DOE-STD-1027-92 (Ref. 3).

- Hazard Category 2

- The quantity of any radionuclide exceeds the Hazard Category 2 threshold quantity provided in Table A.1 of DOE-STD-1027-92 (Ref. 3). This quantity is based on 1 rem at 100 meters (onsite) as determined in 10 CFR 30 and modified by DOE.

- The minimum critical mass limit for any fissile material as specified in ANSI/ANS 8.1 (Ref. 12) is exceeded.

- The total quantity of mixed fission products, where the individual radionuclides have been determined is greater than 1000 curies. 
- Where there are combinations of radioactive materials, the sum of the ratios of the quantity of each radionuclide to the Hazard Category 2 thresholds exceeds 1.0.

- Hazard Category 3

- The quantity of any radionuclide exceeds the Hazard Category 3 threshold quantity provided in Table A.1 of DOE-STD-1027-92 (Ref. 3). This quantity is based on 10 rem at 30 meters based on a 24-hour exposure.

- Where there are combinations of radioactive materials, the sum of the ratios of the quantity of each radionuclide to the Hazard Category 3 thresholds exceeds one.

The criteria for determining if a facility is a Radiological Facility are provided below.

- Radiological Facility .

- Where there are combinations of radioactive materials, the sum of the ratios of the quantity of each radionuclide to the Hazard Category 3 thresholds is less than one but greater than zero (Ref. 3).

- Non-Nuclear or Industrial

- Where the potentially releasable radionuclide inventory is below the RQs of 40 CFR 302.4 Appendix B (Ref. 11). Differentiation between Non-Nuclear and Industrial is determined based on the chemical hazards evaluation (Ref. 4).

\subsubsection{CHEMICAL INVENTORY ASSESSMENT METHODOLOGY}

The assessment of the chemical inventory consists of a comparison of each chemical to the Reportable Quantities (RQs) of 40 CFR 302.4 (Ref. 11), Threshold Quantities (TQs) of 29 CFR 1910.119 (Ref. 13), and the Threshold Planning Quantities (TPQs) of 40 CFR 355 (Ref. 14). The criteria for determining the facility baseline grouping based on the chemical evaluations are established as follows:

- Non-Nuclear

- Where the potentially releasable hazardous material meets or exceeds the .Threshold Quantity (TQ) of 29.CFR 1910.119 (Ref. 13), or

- Where the potentially releasable hazardous material meets or exceeds the Threshold Planning Quantity (TPQ) of 40 CFR 355 (Ref. 14), or

- Where the potentially releasable hazardous material meets or exceeds the Reportable Quantity (RQ) of 40 CFR 302.4, Table 302.4 (Ref. 11).

- Industrial

- Where the potentially releasable hazardous material is below the Reportable Quantity (RQ) of 40 CFR 302.4, Table 302.4 (Ref. 11).

- High Hazard Chemical Facility 
- Where the releasable radiological inventory is below the Reportable Quantities (RQs) for radiological materials, but has any gross chemical inventory greater than the Threshold Quantity (TQ) of 29CFR 1910.119 (Ref. 13) or 40 CFR 68 (Ref. 21). If a chemical does not have a TQ, the Threshold Planning Quantity (TPQ) of 40 CFR 355 (Ref. 14) will be used. (Ref. 2)

- Low Hazard Chemical Facility

- Where the releasable radiological inventory is below the reportable quantities (RQs) of 40 CFR 302 (Ref. 11) for radiological materials, the gross chemical inventory both below the Threshold Quantities (TQs) of 29 CFR 1910.119 (Ref. 13) and 40 CFR 68 (Ref. 21) and releasable chemical inventory at or above the reportable quantities (RQs) of 40 CFR 302, Table 302.4 Levels (Ref. 11). If a chemical does not have a TQ, the Threshold Planning Quantity (TPQ) of 40 CFR 355 (Ref. 14) will be used. (Ref. 2)

\subsection{WASTE STREAM REVIEW}

At this time, all waste streams accepted into the ETF are based on the WAC (Ref. 7). Current operating plans do not indicate an increase in the allowable concentrations permitted by Reference 7. The downgrading of the ETF from a Hazard Category 3 facility to a Radiological facility should have no effect on existing generators since the downgrade is based on recently approved ETF Waste Acceptance Criteria (WAC) (Ref. 22). The WAC is based on historical performance of the upstream processes along with process knowledge of the ETF's capability to remove contaminants.

It is not practical to increase the WAC limits because 1) meeting ALARA release goals for the site (ETF is currently the major dose source for liquid releases), and 2) facility radiological controls (raising the WAC.will result in higher radiation levels within the building, especially around the evaporators). Possible new waste streams may be affected but alternative disposal locations exist for liquid streams with higher radionuclide concentrations, such as CIF, F Canyon Outside Facility and F/H Tank Farms.

To demonstrate margin between the WAC and the DOE-STD-1027-92 limits, the calculations of inventory from which this document is developed (Ref. 15) have calculated the inventory for the basin based on larger concentrations of non-tritium radionuclides than are currently permitted by the WAC. This will not impact the Hazard Category of the ETF, provided that the concentrations remain within the limits given in Reference 16 and the DOE-STD-1027-92 limits for a Radiological Facility. A preliminary review of limited acceptance of a waste stream made up of CIF blowdown material has been performed. The preliminary review, based on estimated radionuclide concentrations, indicated that the resulting increase in radionuclide inventory would not cause the ETF to exceed the DOE-STD-1027-92 limits for a Radiological Facility. A formally documented evaluation must be performed before CIF blowdown material may be considered for acceptance into the ETF. 


\subsection{HAZARDOUS MATERIAL INVENTORY}

The radionuclide inventory for ETF is provided in Reference 15, which indicates that the total estimated radionuclide inventory for each segment of the facility is less than the Category 3 Threshold Limits from DOE-STD-1027-92. The facility segments were taken from the Hazards Assessment Document for the ETF (Ref. 6). Segments 1 and 2 are the same as those in Reference 6. Segments 3 and 4 are the same as Segments 4 and 5, respectively, from Reference 6. Segments 5 and 6 have been composed from the remaining segments. For Segments 5 and 6 , the remaining segments have been divided based on the physical separation of the tanks and equipment. Piping connects the segments and in order to ensure the separation of the segments, as required by DOE-STD-1027-92, administrative controls are provided by References 17,18 , and 19. No release from an event in one segment is judged to result in a total release that exceeds Category 3 Threshold limits.

\subsubsection{SEGMENTS}

\subsubsection{Segment 1-F-Area Cooling Water Basin}

The F-Area cooling water basin is an impermeable storage basin designed to receive diverted cooling water from $F$ Area. The basin is divided into a 500,000-gallon high radioactivity section and a 1,500,000-gallon moderate radioactivity section.

\subsubsection{Segment 2-F-Area Retention Basin}

The F-Area retention basin is a 6,000,000-gallon impermeable storage basin designed to receive storm water from the F-Area waste tank farm. It also receives any diverted cooling water not routed to Segment 1.

\subsubsection{Segment 3-H-Area Cooling Water Basin}

The H-Area cooling water basin has the same function as the F-Area cooling water basin, Segment 1.

\subsubsection{Segment 4-H-Area Retention Basin}

The H-Area retention basin has the same function as the F-Area retention basin, Segment 2 . 


\subsubsection{Segment 5-Lift Stations, Force Main, Wastewater Collection Tanks and Organic Removal}

The F-Area lift station consists of a lift station tank, a diesel generator, and pumps that transfer wastewater from the lift station to the ETF or to the H-Area waste tank farm via a diversion box. The H-Area lift station has the same function as the F-Area lift station. The force main consists of buried pipelines that transport wastewater from the lift stations to the ETF or to the diversion box.

The remainder of Segment 5 consists of two Wastewater Collection Tanks, the Mercury Removal and Carbon Absorption Columns for the Organic Removal System, and chemical storage tanks, including the Nitric Acid Storage Tank and the diked area (241-73H). Segment 5 is separated from Segment 6 by a paved road. Piping provides a connection to the Treatment Building. If an inadvertent release of inventory occurred to the Treatment Building, the inventory release to the Treatment building would not be substantially above the maximum inventory for Segment 6 shown in Reference 15. In order to ensure the separation of this segment from Segment 6 , the facility relies on administrative controls (Ref. 17, 18 and 19). Sufficient margin is maintained that pumping may continue for up to 24 hours without exceeding Category 3 threshold limits for the affected segment.

\subsubsection{Segment 6-Treatment Building, Control Building, Outside Tanks, and HEPAs}

The treatment building contains the process equipment for submicron filtration, reverse osmosis, ion exchange, and evaporation. Outside equipment and tanks include the $\mathrm{pH}$ adjust and feed tanks for the reverse osmosis and ion exchange processes, organic removal feed tank, evaporator condensate hold tank, evaporator feed tanks, High Efficiency Particulate Air (HEPA) filters, fans, stack and three treated water tanks. The Control Building includes the transformer and diesel generator, cooling towers, process water tank, shops, chemical laboratory, health protection laboratory, and personnel change rooms. A storage area consists of the air compressors and a chemical storage area in the treatment building. It is separated from the process areas by firewalls. Also located outside of the treatment building are the day tanks for nitric acid, caustic and sodium nitrate.

\subsubsection{RADIOLOGICAL INVENTORY}

The inventory of each segment will be administratively controlled to ensure that the total inventory of the segment does not exceed the Hazard Category 3 threshold limits for the segment. The maximum inventory available for hold up in the any segment will be procedurally maintained. For example, hold up in process columns, sludge build up, and temporary sources of radionuclide inventory, such as tank trucks, will be subject to administrative controls (Ref. 5).

Input from CIF, Reactors, or other generators that potentially contain fissile material shall be evaluated to ensure that there is negligible hold-up of fissile material within the facility. If this cannot be assured, a fissile inventory control program shall be initiated. 


\subsubsection{CHEMICAL INVENTORY}

The Chemical Inventory for the facility was compiled for References 6 and 20 and shown in Table 2.

\subsection{IMPLEMENTATION OF RADIONUCLIDE INVENTORY CONTROL}

Inventory in each of the facility segments will be controlled to ensure that Hazard Category 3 threshold limits are not exceeded. Procedures will be developed that are sufficiently restrictive to verify that the limits are not exceeded. A timetable for updating records will be developed that is adequate to ensure that facility engineering is aware, before the Hazard Category 3 threshold limits are exceed, that those limits are being approached

Temporary sources of radionuclide inventory may be present in the facility, e.g. tank trucks. Before the temporary sources may enter the area, the total radionuclide inventory of the segment with the truck or stream inventory must be evaluated to ensure that the inventory of the facility remains less than the Hazard Category 3 threshold limits (Ref. 5).

Potential hold-up in Segments 5 and 6 requires more extensive administrative controls. Segments 5 and 6 each contain columns that will retain some radionuclide inventory. Records must be updated at appropriate intervals to ensure that the total inventory of the segment does not exceed the Hazard Category 3 threshold limits for either segment. The radionuclide input and output to the process must be determined and the maximum hold-up in the process areas calculated. By procedure, a determination will be made of the total maximum inventory in each of Segments 5 and 6. A running total of maximum hold-up will be determined. That total will be combined with the WAC based inventory of the segment and any temporary sources of radionuclide inventory that are in the segment. The maximum inventory available for hold up in the columns and elsewhere in the segment will be procedurally maintained, and ETF Engineering will determine the inventory held on the columns, using process knowledge and sampling, as appropriate. Before approaching the Hazard Category 3 threshold limits, the material in the columns will be evaluated for cleanup or replacement, and other hold-up to the building removed, if required to maintain the inventory of the segment below Category 3 threshold limits.

There may be a build-up of sludge in the basins and the sludge may contain a concentration of radionuclides greater than that in the basin water. The calculations used to estimate the basin inventory assume an inventory higher than that permitted by the WAC (Ref. 7). Furthermore, the presence of water over the sludge reduces the source reduction factor for a release. Therefore the record keeping required to ensure that Category 3 threshold limits are not exceeded is less restrictive for the basins than the record keeping required for the columns. The facility is required to sample the sludge at any time that Facility Engineering judges that the total inventory of the basin may be approaching the Hazard Category 3 threshold limits. At least annually facility engineering will evaluate sludge buildup in the basins. This evaluation will include sampling as appropriate. Also, an evaluation of the radionuclide content of the sludge is required whenever activities involving significant exposure of sludge are anticipated (Ref. 5). 
Radionuclide inventory for each of the facility segments will be controlled to ensure that operations do not result in exceeding Hazard Category 3 threshold limits. Administrative Controls will be in place to ensure that the limits are not exceeded.

\subsection{ASSUMPTIONS}

This assessment was predicated on the following assumptions:

1. Evaluation guidelines are based on an airborne release and do not address offsite impacts that may arise due to other pathways.

2. Specific radionuclide inventories for input waste streams were calculated using maximum values from the WAC. Some of the inputs were based on upsets to process conditions at other facilities. Significant margin exists from the inputs to the inventory limits applied (Ref. 3). For output waste streams, specific radionuclide inventories were calculated using maximum values of 175 times the WAC values. Radionuclide inventories for intermediate processes were calculated based on maximum radionuclide concentrations in treatment vessels, provided by ETF Engineering (Ref. 7 and 16):

3. Sampling and inventory control restrictions required by Reference 5 will be enforced

4. Although certain process upsets, e.g. releases from the Tank Farm, may result in ETF inventory that exceeds the Hazard Category 3 or Category 2 threshold limits, these events may never occur. Furthermore, this increased inventory is limited to the basins. These situations result in requirements for additional documentation for appropriately and safely controlling the situation. This Hazard Baseline Downgrade does not address these events.

\subsection{HAZARDOUS MATERIAL INVENTORY ASSESSMENT}

\subsubsection{RADIOLOGICAL INVENTORY ASSESSMENT}

The radiological assessment involved an evaluation of the radionuclide inventory for each segment (Ref. 15). For each facility segment, the radionuclide inventory was compared to the threshold quantities for each radionuclide as provided in Table A.1 of DOE-STD-1027-92 (Ref. 3). Additional inventory will be controlled per Reference 5 .

The criticality hazard was evaluated in Reference 6 .

\subsubsection{CHEMICAL INVENTORY ASSESSMENT}

The chemical assessment involves an evaluation of the chemical inventory. The chemical inventory for the segment is compared to the RQs of 40 CFR 302.4 (Ref. 11) or to the TPQs of 40 CFR 355 (Ref. 14), and TQs of 29 CFR 1910.119 (Ref. 13) and 40 CFR 68.130 (Ref. 21). 
The results of the evaluation are summarized in Table 2. The reportable quantities (RQs) of . mercury, ammonia, sodium hydroxide, and ferric nitrate are exceeded but the published Threshold Quantities (TQs) and Threshold Planning Quantities (TPQs) of any of the chemicals in Table 2 are not exceeded. Therefore the ETF can be considered as a Low Hazard Chemical facility.

The evaluation of chemical hazards does not affect the downgrade of the ETF to a Radiological Facility, but may require development of additional documentation per DOE-STD-5502-94 (Ref. 4).

\subsection{HAZARD BASELINE RESULTS AND CONCLUSIONS}

\subsubsection{RADIOLOGICAL RESULTS}

Table 1 reports the results of the radiological evaluation (Ref. 15). See Reference 6 for confirmation that a criticality event is not çredible in the Effluent Treatment Facility.

\subsubsection{CHEMICAL RESULTS}

Table 2 reports the results of the chemical evaluation.

\subsubsection{CONCLUSIONS}

Table 1 presents the results from the evaluation (Ref.15) of the radiological inventory for each segment in the ETF. Table 1 indicates that each of these segments contains less than the threshold values for a Category 3 facility (Ref. 15). Therefore, in accordance with the definitions provided in DOE Order 5480.23 (Ref.1) and DOE-EM-STD-5502-94 (Ref. 4) the "Baseline Grouping" associated with the ETF is that of a Radiological Facility.

Based on these results, safety documentation consistent with the requirements of DOE-EM-STD5502-94 for radiological facilities is required for the ETF. Furthermore, the results of this Baseline Grouping Assessment indicate that an Auditable Safety Analysis document is required for the ETF per the requirements of Procedure 1.01, A.2, of WSRC 11Q Facility Safety Document Manual. Specifically, Procedure 1.01, A.2, of WSRC 11Q (Ref. 2) states:

"Auditable Safety Analysis (ASA). . . documentation is the safety basis for Radiological, High-Hazard Chemical, and Low-Hazard Chemical Facilities. As such, it serves a function similar to a SAR for those facilities. ASA is a concept more than a stand-alone document. Other documents that contain enough information to satisfy ASA objectives (e.g., PHRs, HASPs) satisfy ASA requirements, provided they meet the requirements of this Manual. In particular, Reference 11 notes the HASP can document the ASA. The objectives are to provide systematic identification of hazards, and describe and analyze the adequacy of measures taken to eliminate, 
control or mitigate identified hazards. If existing safety documents do not provide adequate information, they will be amended or additional information presented in a separate document. ASA is not approved by or sent to DOE, except for High-Hazard Chemical Facilities. The ASA will be maintained in an auditable fashion."

The evaluation of chemical hazards does not affect the downgrade of the ETF to a Radiological Facility, but may require development of additional documentation per DOE-STD-5502-94. The ETF is classified as a Low Hazard Chemical Facility based on chemical hazards in accordance with Reference 2. Non-Nuclear Facility Documentation is required per DOE-STD-5502-94. As a facility which is involved in hazardous waste activities (Ref. 10), a Health and Safety Plan (HASP) must be performed, and the ASA may be a part of the HASP. DOE-STD-5502-94 also indicates that Administrative Controls and a Safety Analysis per DOE Order 5481.1B are required. The Administrative Controls may also be incorporated into the HASP. However, DOE Order 5481.1B has been canceled, and no additional Safety Analysis, beyond the ASA/HASP, is required at this time.

The results and conclusions of this assessment are not valid for inventories greater than those used in the analysis but are valid if controlled within Hazard Category 3 threshold limits (Ref. 5 and 15). 


\subsection{DOWNGRADE RESULTS AND CONCLUSIONS}

1. Results of this Hazard Baseline Downgrade support the Effluent Treatment Facility (ETF) downgrade to a Radiological Facility.

2. Based on Chemical Hazards, the ETF is classified as a Low Hazard Chemical ... Facility (The evaluation of chemical hazards does not affect the downgrade of the ETF to a Radiological Facility but may require development of additional documentation per DOE-STD-5502-94 (Ref. 4).)

3. An Auditable Safety Analysis (ASA) must be developed for the ETF. .

4. A Health and Safety Plan (HASP) is required. The ASA and Administrative Controls will be incorporated in the HASP. Significant chemical hazards in the ETF will be evaluated in this document.

\subsection{SCHEDULE}

Per Reference 4, the evaluation of chemical hazards as part of the baseline grouping assessment for the ETF.may result in requirements to develop additional documentation (Refs 14 and 19).

\begin{tabular}{|l|l|l|}
\hline Document & Completion Status & Date \\
\hline $\begin{array}{l}\text { ETF Hazard Baseline Downgrade, } \\
\text { Rev. 0. }\end{array}$ & Issued. & March 17, 1998 \\
\hline $\begin{array}{l}\text { ETF Hazard Baseline Downgrade, } \\
\text { Rev. 1 (Radiological and Chemical } \\
\text { Hazard Baseline Grouping) }\end{array}$ & Issued & September 30, 1998 \\
\hline Draft ETF ASA/HASP & In Progress & November 13, 1998 \\
\hline ETF ASA/HASP WSRC Approval & & January 8, 1999 \\
\hline
\end{tabular}

\subsection{REFERENCES}

1. Nuclear Safety Analysis Reports. DOE Order 5480.23, U.S. Department of Energy, Washington, DC, April 30, 1992.

2. Facility Safety Document Manual. WSRC 11Q, Rev. 2, Westinghouse Savannah River. Company, Aiken, SC, June 30, 1998.

3. Hazard Categorization and Accident Analysis Techniques for Compliance with DOE Order 5480.23. Nuclear Safety Analysis Reports. DOE-STD-1027-92, Change Notice No. 1, U.S. Department of Energy, Washington, DC, September 1997. 
4. Hazard Baseline Documentation. DOE-EM-STD-5502-94, U.S. Department of Energy, Washington, DC, August 1994

5. Nadeau, M.A. Methodology for Determining Increases in Radionuclide Inventories for the Effluent Treatment Facility Process. WSRC-TR-98-00257, Rev. 0, Westinghouse Savannah River Company, Aiken, SC, July 1998.

6. Nadeau, M.A. Hazards Assessment Document Effluent Treatment Facility, Balance of Plant. WSRC-TR-93-031, Rev. 1, Westinghouse Savannah River Company, Aiken, SC, April 12, 1993.

4. Aponte, C.I. and Poirier, M.R. Waste Acceptance Criteria for the F/H Effluent Treatment Facility (U). X-SD-G-00003, Rev. 0, Westinghouse Savannah River Company, Aiken, SC, March 1997.

8. SWMD.Authorization/Safety Basis Lists Manual (U). WSRC-IM-95-28, Rev. 9, Westinghouse Savannah River Company, Aiken, SC, February 10, 1998

9. Not used.

-10. Effluent Treatment Facility Systems Overview (U). WETIS003, Rev. 0, Westinghouse Savannah River Company, Aiken, SC, August 13, 1995.

- 11. "Protection of the Environment," Title 40 Code of Federal Regulations, Part 302.4, Designation, Reportable Quantities, and Notification. U.S. Environmental Protection Agency, Washington, DC, July 1992.

$\checkmark$ 12. Safety In Operations With Fissionable Materials Outside Reactors. ANSI/ANS-8.1. American Nuclear Society, La Grange Park, IL, October 7, 1983.

U13. "Labor," Title 29 Code of Federal Regulations, Part 1910.119(e)(6), Process Safety Management Of Highly Hazardous Chemicals. U.S. Department of Labor, Washington, DC, May 26, 1992.

14. "Protection of the Environment," Title 40 Code of Federal Regulations, Part 355, Emergency Planning and Notification. U. S. Environmental Protection Agency, Washington, DC, July 1992.

15. Nadeau, M.A. Radiological Segment Inventories for the ETF and Comparison to DOE STD-1027-92 Threshold Limits (U). S-CLC-H-00640, Rev. 1, Westinghouse Safety Management Solutions, Aiken SC, July 1998.

16. Watkins, R.W. Effluent Treatment Facility Radionuclide Inventory. SWD-ETF-98-017, Rev. 1, Westinghouse Savannah River Company, Aiken SC, July 21, 1998. 
A7. Abnormal Operating Procedure Manual (U). SW22.4-AOP-01, Rev. 0, WestinghouseSavannah River Company, Aiken SC, March 30, 1998.

48. Emergency Operating Procedure Manual (U). SW22.5-EOP-01, Rev. 0, Westinghouse Savannah River Company, Aiken SC, March 31, 1998.

19. ETF Facility Operating Manual Integrated Operating Procedure (U), WasteWater Processing (U). SW22.2-IOP-1, Rev.1, Westinghouse Savannah River Company, Aiken SC, March 2, 1998.

20. Hadlock, D., Emergency Preparedness Hazards Assessment for the Consolidated Incinerator Facility, Solvent Storage Facility, Effluent Treatment Facility, and Saltstone Facility (U). S-EHA-G-00004, Rev. 0, Westinghouse Savannah River Company, Aiken
SC, March 31, 1998.

21. “Accidental Release Prevention Requirements : Risk Management Programs Under Clean Air Act", Title 40 Code of Federal Regulations, Part 68, March 1995.

22. Acceptance Criteria, WSRC 1S, WAC 4.02, Westinghouse Savannah River Company, 


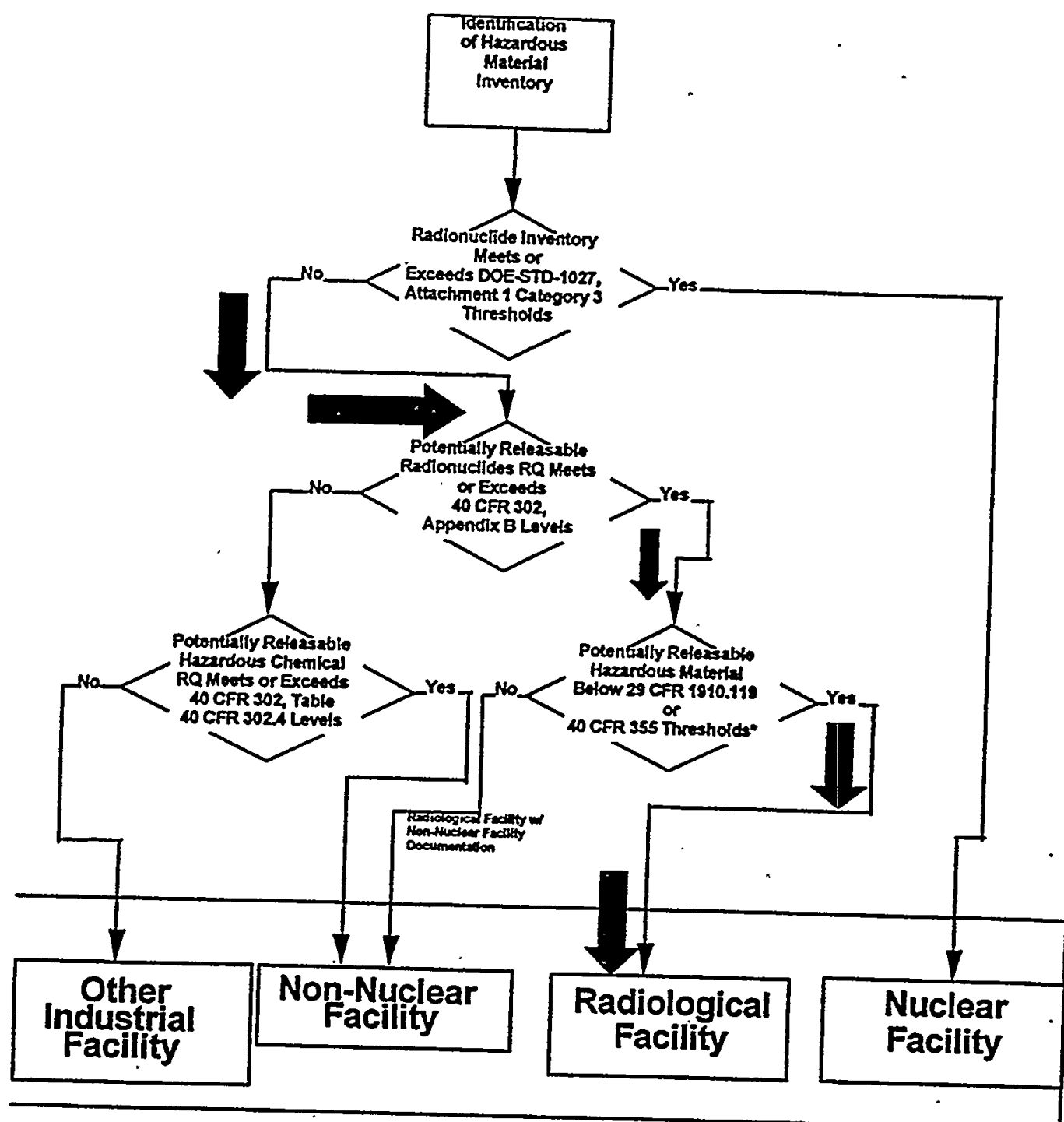

\section{Hazard Baseline}

-If chemicals are not IIstod In 29CFR1910.119

$=$ Path taken by ETF

Figure 1 Determination of Baseline Grouping 
Table 1 Radiological Inventory Evaluation of the ETF Facility Segments

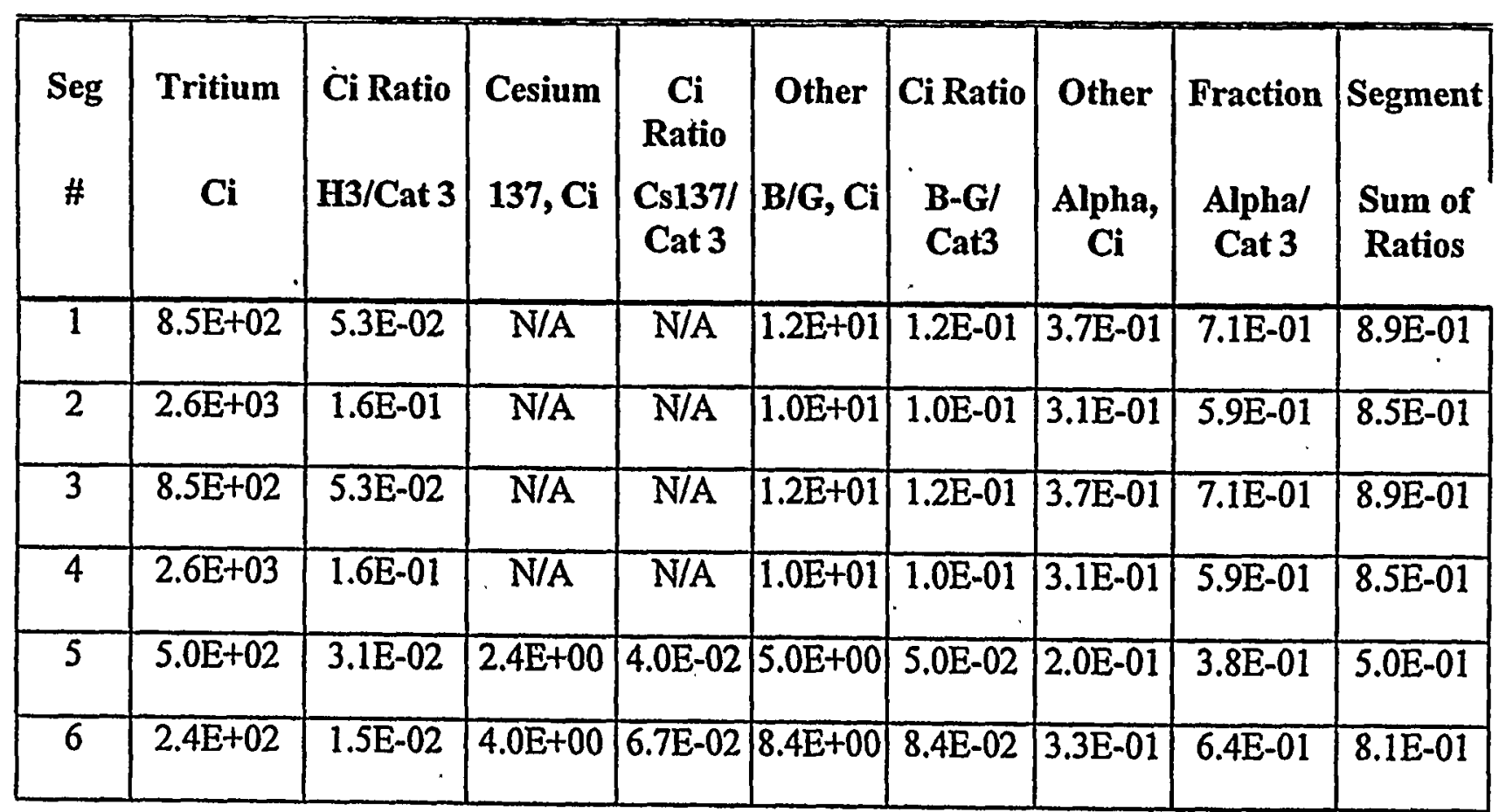


Table 2 Chemical Inventory Evaluation of the ETF Facility Segments

\begin{tabular}{|c|c|c|c|c|c|c|c|c|c|c|c|c|}
\hline \multirow[t]{2}{*}{ Chemical } & \multicolumn{4}{|c|}{ SEGMENT 5} & \multicolumn{4}{|c|}{ SEGMENT 6} & \multirow[t]{2}{*}{$\overline{\mathbf{R Q}}$} & \multirow[t]{2}{*}{ TPQ } & \multicolumn{2}{|c|}{ TQ } \\
\hline & $\begin{array}{l}\text { WWC } \\
\text { Tanks }\end{array}$ & $\begin{array}{c}\text { Acid \& } \\
\text { Caustic } \\
\text { Tanks }\end{array}$ & $\begin{array}{c}8 . \\
\text { DIKED } \\
\text { AREA } \\
(241-73 H)\end{array}$ & TOTAL & $\begin{array}{l}\text { Treat. } \\
\text { Bldg. }\end{array}$ & $\begin{array}{c}\text { Storage } \\
\text { Area }\end{array}$ & $\begin{array}{l}\text { Process } \\
\text { Chem. } \\
\text { Tanks }\end{array}$ & TOTAL & & & $\begin{array}{l}\text { OSHA } \\
\text { PSM }\end{array}$ & $\begin{array}{l}\text { EPA } \\
\text { RMP }\end{array}$ \\
\hline Mercury & - & - & 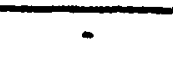 & - & $5.79 \mathrm{E}+03 \mathrm{~g}$ & - & - & $5.79 \mathrm{E}+03 \mathrm{~g}$ & $4.54 \mathrm{E}+02 \mathrm{~g}$ & NL & NL & NL \\
\hline Lead & $4.41 \mathrm{E}+02 \mathrm{~g}$ & $\therefore$ & - & $4.41 \mathrm{E}+02 \mathrm{~g}$ & $3.39 E+02 g$ & 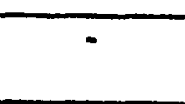 & - & $3.39 \mathrm{E}+02 \mathrm{~g}$ & $\begin{array}{c}4.540 \mathrm{E}+03 \\
\mathrm{~g}\end{array}$ & $\overline{N L}$ & NL & NL \\
\hline Ammonia & $5.51 \mathrm{E}+04 \mathrm{~g}$ & - & - & $5.51 \mathrm{E}+04 \mathrm{~g}$ & $5.85 \mathrm{E}+04 \mathrm{~g}$ & 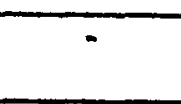 & - & $5.85 \mathrm{E}+04 \mathrm{~g}$ & $\begin{array}{c}4.5400 \mathrm{E}+0 \\
4 \mathrm{~g}\end{array}$ & $2.27 \mathrm{E}+05 \mathrm{~g}$ & $\begin{array}{c}.54 \mathrm{E}+ \\
06 \mathrm{~g}\end{array}$ & $\overline{N L}$ \\
\hline $\begin{array}{l}45 \% \text { Nitric } \\
\text { Acid }\end{array}$ & - & $3.68 \mathrm{E}+07 \mathrm{~g}$ & - & $3.68 \mathrm{E}+07 \mathrm{~g}$ & $=$ & $2.12 \mathrm{E}+05 \mathrm{~g}$ & $7.41 \mathrm{E}+06 \mathrm{~g}$ & $7.622 \mathrm{E} 06 \mathrm{~g}$ & NL & NL & NL & NL \\
\hline $\begin{array}{l}\text { Oxalic } \\
\text { Acid }\end{array}$ & $=$ & - & - & - & - & $1.14 \mathrm{E}+07 \mathrm{~g}$ & - & $1.14 \mathrm{E}+07 \mathrm{~g}$ & NL & $\overline{N L}$ & $\overline{N L}$ & $\overline{\mathrm{NL}}$ \\
\hline $\begin{array}{l}\text { Sodium } \\
\text { Hydroxide }\end{array}$ & - & $4.07 \mathrm{E}+07 \mathrm{~g}$ & - & $4.07 \mathrm{E}+07 \mathrm{~g}$ & - & $3.02 \mathrm{E}+05 \mathrm{~g}$ & $2.81 E+06 g$ & $3.11 \mathrm{E}+06 \mathrm{~g}$ & $4.54 \mathrm{E}+05 \mathrm{~g}$ & NL & $\overline{\mathrm{NL}}$ & $\overline{N L}$ \\
\hline $\begin{array}{l}\text { Aluminum } \\
\text { Nitrate }\end{array}$ & $\because$ & - & $\begin{array}{l}10,000 \\
\text { gallons }\end{array}$ & $\begin{array}{l}10,000 \\
\text { gallons }\end{array}$ & - & - & - & $\because$ & NL & $\overline{N L}$ & $\overline{N L}$ & NL \\
\hline $\begin{array}{l}\text { Ferric } \\
\text { Nitrate }\end{array}$ & - & $=$ & $\begin{array}{l}10,000 \\
\text { gallons }\end{array}$ & $\begin{array}{l}10,000 \\
\text { gallons }\end{array}$ & - & - & - & $\because$ & $1,000 \mathrm{lbs}$ & $\overline{N L}$ & NL & NL \\
\hline
\end{tabular}

